\title{
Indium In 111 Monoclonal Antibody BrE-3
}

National Cancer Institute

\section{Source}

National Cancer Institute. Indium In 111 Monoclonal Antibody BrE-3. NCI Thesaurus.

Code C2608.

A humanized monoclonal antibody conjug ated to the imag ing radioisotope (indium-111).

This radioimmunoconjug ate binds to the breast epithelial mucin antigen, which is found primarily on breast cancer cells, permitting radioactive immunodetection of mucinpositive tumor cells and an estimate of radiation dosimetry prior to administration of cytotoxic radiotherapy. ( $\mathrm{NCl} 04)$ 